\title{
Determinants in Project Management and Change Processes in the Operations of an Organisation
}

\author{
BEATA SKOWRON-GRABOWSKA \\ Management Faculty \\ Czestochowa University of Technology \\ ul. Dabrowskiego 69, 42-201 Czestochowa \\ POLAND
}

\begin{abstract}
The purpose of the article is to present primary conditions in the process of project management in organisations. Ontology, terminology, axiology and epistemology were taken into account in particular. Many elements of the projects which generate improvement of the efficiency of the organisation in the context of a systemic approach, such as common values, organisation goals and change management were also listed. Furthermore, project's preparation is presented in the paper. Rating in the area of challenges, barriers and trends in project management were highlighted on the basis of answers provided by project managers. Taking into account the results of empirical research, it was assumed that the arithmetic mean of ratings indicates the importance of challenges, barriers and trends for project management in organisations. This article develops previous researches on existing theories of project management and change processes. As a result, it has become reasonable to assume the hypothesis that the project implementation time is determined by the rating of challenges, barriers and trends in project management; higher ratings of challenges and trends and lower rating of barriers lead to shorter project implementation times.
\end{abstract}

Key-Words: - project management, organization, process, change, operation management, technology

Received: December 1, 2020. Revised: August 20, 2021. Accepted: August 23, 2021. Published: August 26, 2021.

\section{Introduction}

Dynamic economic changes create development challenges for organisations. Development is determined as a result of multiple different organisational measures. Among these measures a significant position is taken by projects which, when properly managed and responding to the challenges of the economy, enable the development of the organisation.

Project management foundations require elements which include common values together with the goals of the organisation. These elements affect the success of the project, evaluated using the criteria of purpose, feasibility, effectiveness, utility and efficiency.

Meeting the criteria is required from the personnel preparing and implementing projects. Personnel competences, in particular the appreciation of the substantive complexity, occurring in the processes of project management, are key in successfully facing challenges and conditions by the organisation. The challenges focus on the development of the organisation. Barriers and trends in project management are assumed to be the primary conditions.

Improving analysis in this context requires the use of appropriate projects preparation and implementation methods. The appropriate methods were adopted as algorithms for working with the most characteristic features that enable further assessment of the relations in project management in terms of challenges and conditions - barriers and trends in the decisions of project staff. Some relevant studies can be found in [1] and [2].

\section{Primary Conditions for Project Management in Organisations}

Business activities are subject to continuous change processes in terms of their nature and methods of activity. Changes in business activity require their systematisation and definition of areas and objectives for the organisation. The implementation of activities in this scope is made possible by projects that build creative cooperation between business, science, education and administration. [3] As a result of this cooperation, projects can be developed that respond to the challenges of the economy that changes theoretical concepts in management. These concepts determine the primary conditions of project activity in organisations.

Taking into account the theory of management, the essence of the project can be identified as a set of activities undertaken over a certain period of time, 
which ensure the implementation of singular tasks. [4] Their implementation requires the commitment of resources and a positive financial result. [5] The nature of project activities based on integration and relationships resulted in the development of the project management concept - defining the tools, planning and work organisation techniques used for large undertakings. In further consideration, it was assumed that "project management is a set of managerial activities required to bring a project to a positive conclusion. [6]

According to $\mathrm{M}$. Trocki, project management involves a noticeable process of development in deficit areas and taking up new challenges in theory and practice. Methodological basis, analysis of research concepts together with paradigms of management sciences are among important challenges. In this context, four research approaches can be identified for operational, process, organisational and sustainable project management. In approaches of this kind, a substantive distinctiveness in terms of conceptual and conditionality is noticeable. The conditions are mainly: ontology, terminology, axiology and epistemology. [7]

The foundations of project management justify the inclusion of many elements, such as: common values and objectives of the organisation as well as change management. Change management processes are typically generated by projects implemented to achieve business objectives of increasing revenue and improving profitability while increasing customer satisfaction and improving product quality. [8]

The requirements and quality challenges arise primarily from the system of standards formulated by customers. [9] These requirements result in: [10] "- understanding the customer value creation mechanism,

- deep understanding of customer's challenges, and - performance targets shared with customers."

The challenges and requirements of consumers are reflected primarily in the creation of project and company value. [11] The value of a company can be considered in the context of three perspectives: processes that combine business and social activity, common goals and the approved and implemented social mission. [12] (Fig. 1)

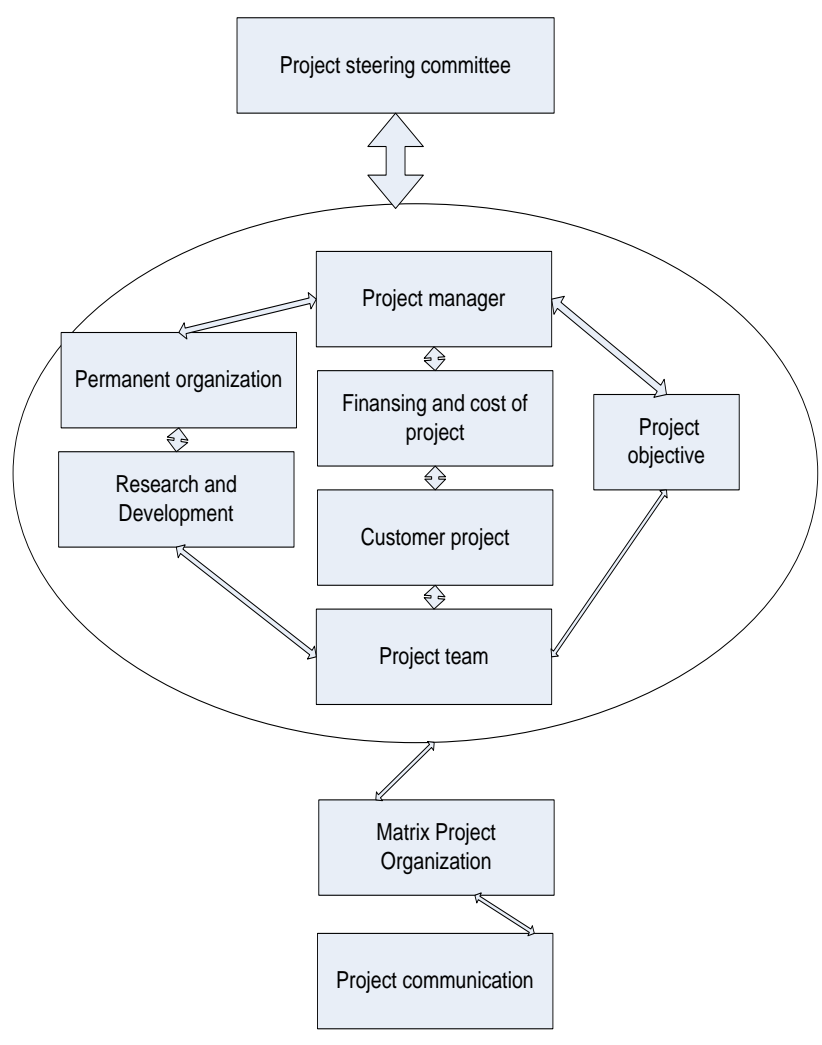

Fig.1: Example of project organization

Source: based on [13]

The figure shows that the preparation of the project is the result of constant changes in organisations as a consequence of consumer requirements. Project managers and teams take into account the effects of $\mathrm{R} \& \mathrm{D}$ activities and project costs when determining the project goals. On the basis of the resources of the organisation, a project matrix is created with the project's communication and organisational culture in teams throughout the organisation. [14] Project activity is primarily determined by human resources, which determine the efficiency and effectiveness of undertakings in organisations.

The efficiency and effectiveness of the personnel is determined by their competences. [15] Project managers are in a special position in the management system, the following are required from them: [16]

- knowledge and negotiating potential in project management processes,

- perception of the complexity of negotiation problems occurring in project management processes,

- analysis and assessment of the scale of difficulties in negotiations,

- understanding of the importance of the conditions and negotiation data in the projects, 
- identification of negotiating partners and their expectations,

- analytical competence regarding the external conditions in design processes.

Projects should therefore primarily involve management processes.[17] Proper management affects the effectiveness of projects. [18] The main goal of the project approach in the organisation's strategies is to improve efficiency. The strategic advantages of project management are an effect of the potential for linking to other management systems. They include: TQM, risk management, change management - which ensure that multiple effects are achieved. The benefits of this type of system integration are presented in Table 1

Table 1. Project management and management systems

\begin{tabular}{|l|l|l|}
\hline \multicolumn{2}{|c|}{ Benefits of project management in relation to systems } \\
\hline TQM & \multicolumn{1}{|c|}{ Risk Management } & \multicolumn{1}{c|}{ Change management } \\
\hline Higher quality products & $\begin{array}{l}\text { Better procedures for identifying risks } \\
\text { and quantifying them }\end{array}$ & $\begin{array}{l}\text { Ability to respond quickly to } \\
\text { customer change requests }\end{array}$ \\
\hline $\begin{array}{l}\text { Higher customer satisfaction } \\
\text { rate }\end{array}$ & $\begin{array}{l}\text { More effective risk response } \\
\text { processes }\end{array}$ & $\begin{array}{l}\text { Reducing the budgetary and } \\
\text { timing impact of changes }\end{array}$ \\
\hline $\begin{array}{l}\text { Less internal and external } \\
\text { failures }\end{array}$ & $\begin{array}{l}\text { More effective decision-making } \\
\text { processes }\end{array}$ & $\begin{array}{l}\text { Increased number of own actions } \\
\text { leading to increased value offered } \\
\text { to customers }\end{array}$ \\
\hline Less production defects & $\begin{array}{l}\text { Increasing the tolerance level for risk } \\
\text { acceptance }\end{array}$ & Good relations with customers \\
\hline $\begin{array}{l}\text { Less complaints and warranty } \\
\text { repairs }\end{array}$ & $\begin{array}{l}\text { More explicit definition in the } \\
\text { contracts concluded of the parties } \\
\text { responsible for managing particular } \\
\text { risks }\end{array}$ & Increasing customer satisfaction \\
\hline
\end{tabular}

Source [8]

The benefits listed above create integration perspectives in management processes with high chances of successful implementation.

Many mutually connected and interdependent factors determine the success of a project. The effective implementation of projects is influenced not only by a wide range of performance conditions, but also by the specific features of individual projects. [19]

It is also crucial to emphasise the importance of the risks affecting the success of the project.

"Project management integration will most probably continue, with change communication being dispersed among a community that would be better able to handle complex change." [20]

Furthermore, it is noted that the scale of the project's success can be assessed by criteria relating to the project's characteristics such as relevance, feasibility, effectiveness, practical utility and efficiency.[7]

Project accomplishment within time, cost, aim and maintaining quality throughout are very common scopes of success factors mentioned by project management professional companies and the researchers.

"Successful project management increases the opportunities for follow up orders for a supplier who becomes an in-supplier for a certain customer or in a country compared to an out-supplier." [18]

It is also justified to present the dysfunctions of a systemic approach to project management, such as: scarcity of goods, waste of time or failure to meet deadlines, which affect the decision-making processes. It is then possible to point to logistics channels, distribution centres from the perspective of project planning and implementation. At this time, a concept of the critical chain as a way of implementing projects, taking into account the criteria of time, budget and substantive content is developed. [21] Project completion within time, budget and aim as well as keeping quality throughout are very common dimensions of success factors, as well as barriers, mentioned by project management professional companies and the researchers. It is inspiring that research focus on project organization is increasing and research interest in the areas of performance of project management is huge.

The literature points to the formal boundaries perceived by employees between the company where they are employed and other organisations cooperating in the preparation and implementation of the project. The importance of formal and mental boundaries in the design activity of the managerial staff and employee teams is stressed. [22] 
It should be noted that in the surveys regarding the acquisition of European funds, many barriers in this process have been identified. Respondents considered the following as the most important barriers:[4]

- lack of qualified staff in the area of project preparation and implementation approx. $33 \%$ of responses,

- high and complex level of project procedures, $21 \%$ of responses,

- complicated rules of accounting for projects, $31 \%$ of responses,

- monitoring and control of project management, $15 \%$ of responses.

It can be pointed out that the conclusions of the author of the article are similar to the conclusions presented by A. Godziewska-Nowicka. This researcher states that the main reason for the difficulties in obtaining projects is the economic barrier, i.e. the lack of sufficient funds for the notified projects. Furthermore, she emphasises that the shortage of staff in the field of project management can still be regarded as a significant obstacle.[23] Project management processes are an important and complex decision-making problem determined by the goal of the organisation which aims to develop its activities through projects. Development-oriented activities require changes that enable the organisation to increase its effectiveness. These expectations are met by appropriate methods of project preparation and implementation. Current literature highlights the importance of project management in evaluating, prioritizing, and selecting those projects which will be successful.

\section{Methods of Project Preparation and Implementation}

The complexity of the project management issues and their importance results in creating a multitude of various methods used in the process of project preparation and implementation. The methods of project preparation are adapted to its nature, scope, customer requirements and challenges for consumers. Methodological unambiguity is ensured by appropriate procedural mechanisms.

The project management method is a practical tool to manage change in the organisation. [24] The development of standards, procedures and general principles in project activities is required from the organisation preparing the project. The organisation formulates requirements for specific structures and the project manager, who is responsible for: [24]

- developing a proposal for project preparation,

- submitting an application,

- signing the project implementation agreement,

- project implementation,

- finalisation of the project objective and financial settlements.

The methodological approach is related to project risk management, which focuses on the identification, analysis and estimation of risks in the project. It is also important to control and adjust the project activities in order to reduce the risks and ensure the chances of successful project implementation. [25]

The expanding range of methods in project management indicates the high potential of blockchain as a new technology of information flow and knowledge used in the processes of distributed database applications.

According to J. Kisielnicki, blockchain technology is the basis for the description of the project implementation in terms of information and knowledge exchange. [27] The implementation of projects requires project management, i.e. a set of logically structured activities, usually not fully defined to achieve the project objective. The primary element of management is the block, with a unit block showing a cause-and-effect relationship with other blocks - thus, creating a blockchain. There are elements in each block that allow them to be chained together. The list of tasks with a time investment forecast called sprint blocklog is an important part of the process.

The introduction includes a description of the reference point in relation to the preceding block, the so-called hash, the time distinguishing feature of the block. The data block contains a hash tree for implementing security systems. Then, it is possible to search for a specific task according to a specific hash. The sequence of tasks is extended by the emergence of new blocks. Closing a block filled with information creates more blocks. This type of project results in the formation of a "blockchain". [26]

The implementation of blockchain technology brings many benefits. Among them, containing all the data regarding the implementation of project activities in the system is of crucial importance. The decentralised nature of the technology affects the participation of each person involved in the project in the form of transmission and 
authentication of tasks. This technology is based on the principle of equality of access to information used in project management, which is considered a significant novelty in management practice. The following features of blockchain also deserve recognition:[27]

$$
\begin{aligned}
& \text { - reliability, } \\
& \text { - transparency, } \\
& \text { - durability, } \\
& \text { - irreversibility, } \\
& \text { - digitisation. }
\end{aligned}
$$

These features enable achieving positive results in project management. However, it is also noted that blockchain technology is relatively expensive. When implementing blockchain technology in project management, it is therefore necessary to carry out a multi-faceted analysis from the point of view of the cost-effectiveness of the projects in terms of objectives and market challenges (Fig. 2)

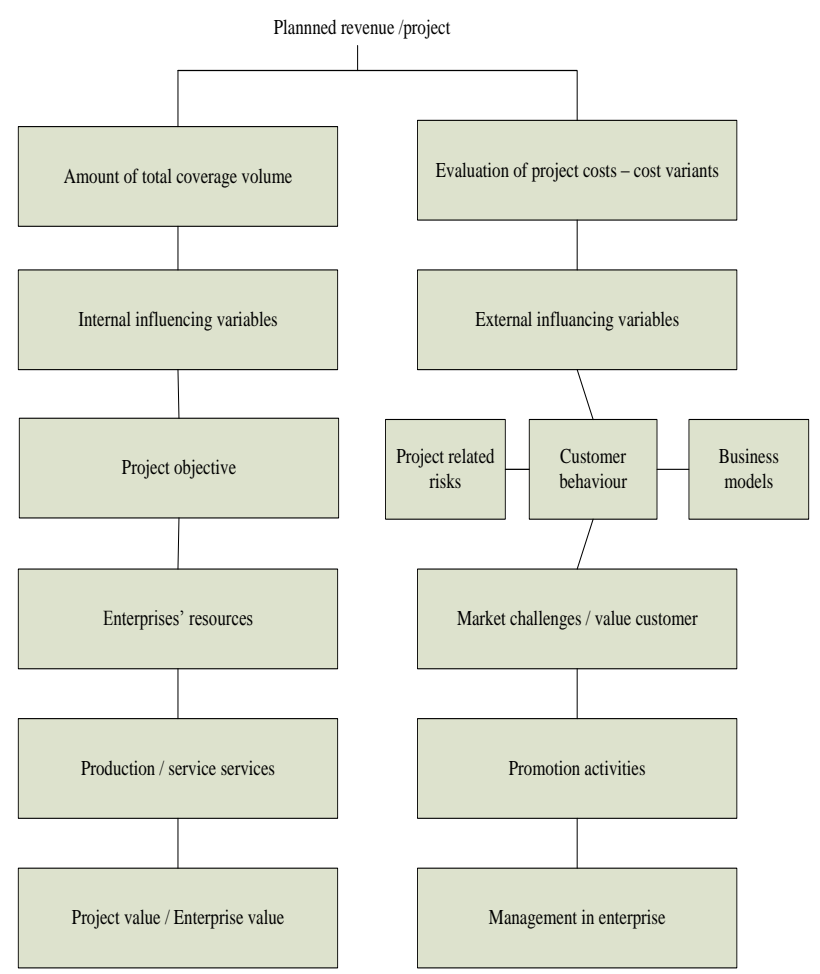

Fig.2: Coverage requirement influencing variables in project activities

Source: [28]

The elements and relationships shown in the figure indicate internal and external influencing variables. The goal of the project is subordinated to consumer behaviour which determines business models and has a direct impact on the value of the project and the company [28]. Model solutions correspond to the area of challenges, trends and barriers in project management in organisations. As a result of which the following stages were distinguished: [29]

- the first stage focuses on presenting a brief characteristic of the study sample,

- the second stage is to refer to the results of the research on the challenges of the main trends and barriers to the development of project management,

- the third stage consists of developing a proprietary concept.

These stages systematise methodically project activities with different inspirations

In the process of project management, it is reasonable to emphasise the trends and scope of development of project activities. The project management basis points to concepts formulated in the course of the implementation of large industrial projects in the form of smart grids. [30] The concept has resulted in the development of standards, methodologies and norms by many international organisations. The procedures mainly take into account the planning, organisation and implementation of project objectives. The dynamics of the environment and the increase in complexity of many projects have resulted in a change in the approach to project management. The changes concerned in particular the inclusion of systems theory and chaos theory and the functioning of project teams. As a consequence, the new direction in project management takes into account the dynamics of phenomena, multiplicity of causes and networking. [31] This direction shows high usefulness in project management. [32] Based on a literature review, [33] [34] [35] challenges, barriers and trends in project management in companies were identified. Table 2 presents individual areas with the mean rating for a given factor, estimated based on the opinion of managers/experts of projects implemented in the surveyed entities. The average grade is the arithmetic mean of all the collected rankings, expressed on a five-point Likert scale, where 1 is not important at all and 5 is very important. 
Table 2. Average ratings for challenges, barriers and trends in project management

\begin{tabular}{|c|c|c|c|c|c|c|}
\hline No. & Challenges & $\begin{array}{l}\text { Average } \\
\text { rating }\end{array}$ & Barriers & $\begin{array}{l}\text { Ratings } \\
\text { average }\end{array}$ & Trends & $\begin{array}{l}\text { Ratings } \\
\text { average }\end{array}$ \\
\hline 1 & $\begin{array}{l}\text { Timeliness of } \\
\text { the project }\end{array}$ & 4.8 & $\begin{array}{l}\text { Lack of top } \\
\text { management } \\
\text { support }\end{array}$ & 4.8 & $\begin{array}{l}\text { Implementation of } \\
\text { modern project } \\
\text { management methods }\end{array}$ & 4.6 \\
\hline 2 & $\begin{array}{l}\text { Meeting } \\
\text { customer } \\
\text { requirements }\end{array}$ & 4.7 & $\begin{array}{l}\text { Organisational } \\
\text { culture not } \\
\text { conducive to the } \\
\text { implementation } \\
\text { of projects }\end{array}$ & 4.5 & $\begin{array}{l}\text { Development of inter- } \\
\text { organisational projects }\end{array}$ & 4.4 \\
\hline 3 & $\begin{array}{l}\text { Motivating } \\
\text { team members }\end{array}$ & 4.7 & $\begin{array}{l}\text { Lack of } \\
\text { resources for } \\
\text { effective project } \\
\text { management }\end{array}$ & 4.0 & $\begin{array}{l}\text { Use of innovative } \\
\text { technologies to support } \\
\text { the work of managers }\end{array}$ & 4.3 \\
\hline 4 & $\begin{array}{l}\text { Achievement } \\
\text { of objectives }\end{array}$ & 4.5 & $\begin{array}{l}\text { Failure to see } \\
\text { the benefits of } \\
\text { project } \\
\text { management in } \\
\text { the company }\end{array}$ & 3.8 & $\begin{array}{l}\text { Increase in non- } \\
\text { financial incentives }\end{array}$ & 3.6 \\
\hline 5 & $\begin{array}{l}\text { Effective } \\
\text { project risk } \\
\text { management }\end{array}$ & 4.1 & \multirow{4}{*}{$\begin{array}{l}\text { Failure to see } \\
\text { the increase in } \\
\text { efficiency of } \\
\text { company } \\
\text { management } \\
\text { through projects }\end{array}$} & \multirow[t]{4}{*}{3.4} & $\begin{array}{l}\text { Emphasis on } \\
\text { sustainability and } \\
\text { social responsibility in } \\
\text { projects }\end{array}$ & 3.3 \\
\hline 6 & $\begin{array}{l}\text { Proper } \\
\text { planning of } \\
\text { activities }\end{array}$ & 3.2 . & & & $\begin{array}{l}\text { Increased importance } \\
\text { of mega-projects }\end{array}$ & 3.1 \\
\hline 7 & $\begin{array}{l}\text { Meeting the } \\
\text { budget }\end{array}$ & 3.1 & & & \multirow{2}{*}{$\begin{array}{l}\text { Increased validity of } \\
\text { international } \\
\text { certificates }\end{array}$} & \multirow[t]{2}{*}{2.8} \\
\hline 8 & $\begin{array}{l}\text { Efficient } \\
\text { communication } \\
\text { in the team }\end{array}$ & 2.9 & & & & \\
\hline
\end{tabular}

Source: [29]

The identified factors for each of the highlighted areas became the basis for indicating the relationship between them and the average time of implementation and completion of the project in the company, which was as follows:

- over 7 years - $13 \%$ of companies,

- from 5 years to 7 years $-17 \%$ of companies,

- from 2 years to 5 years - $33 \%$ of companies,

- from 1 to 2 years - $25 \%$ of companies,

- under 1 year - $12 \%$ of companies.

In order to investigate the relationship between the time of implementation of the project in the entity and further on the project approach and the challenges, barriers and trends, a multiple regression model has been used to quantify the relationship between multiple independent (explanatory) variables and the dependent (explained) variable. In this study, the time of project implementation in the surveyed companies was identified as an independent variable (marked as Y). In turn, the dependent variables comprise three Xji data sets:

1. Set of variables $\mathrm{X}_{\mathrm{Wi}_{\mathrm{i}}}$ - "Challenges", where $X_{\mathrm{w} 1}, X_{\mathrm{w} 2}, X_{\mathrm{w} 3}, X_{\mathrm{w} 4}, X_{\mathrm{w} 5}, X_{\mathrm{w} 6}, X_{\mathrm{w} 7}, X_{\mathrm{w} 8}$ belong in the set;

2. Set of variables $\mathrm{X}_{\mathrm{Bi}}$ - "Barriers", where $\mathrm{X}_{\mathrm{B} 1}, \mathrm{X}_{\mathrm{B} 2}, \mathrm{X}_{\mathrm{B} 3}, \mathrm{X}_{\mathrm{B} 4}, \mathrm{X}_{\mathrm{B} 5}$ belong in the set;

3. Set of variables $X_{T i}$ - "Trends", where $X_{T 1}$, $\mathrm{X}_{\mathrm{T} 2}, \mathrm{X}_{\mathrm{T} 3}, \mathrm{X}_{\mathrm{T} 4}, \mathrm{X}_{\mathrm{T} 5}, \mathrm{X}_{\mathrm{T} 6}, \mathrm{X}_{\mathrm{T} 7}$ belong in the set;

$* 1,2,3 \ldots$ and denotes the consecutive numbers of the variables in Table 1 , while $\mathrm{j}=\mathrm{W}$ or $\mathrm{B}$ or $\mathrm{T}$.

The goal of the study is to indicate the relationship between the time of implementation of the project approach in enterprises and the rating of challenges, barriers and trends in project management in the surveyed entities. For this purpose, the following research hypotheses were formulated: 
H0: Evaluation of the perception of challenges, barriers and trends in project management influences the time of the whole project. The higher the challenges and trends and the lower the barriers, the shorter the project implementation time in the company.

The impact of the set and $\{\mathrm{XW} 1, \mathrm{XW} 2, \ldots, \mathrm{XWi}$; $\{\mathrm{XB} 1, \mathrm{XB} 2, \ldots, \mathrm{XBi}\}$ and $\{\mathrm{XT} 1, \mathrm{XT} 2, \ldots, \mathrm{XT} i\}$ on the $\mathrm{Y}$ variable should be considered.

Estimation of the regression equation from the nelement sample has the following form:

$y_{t}=\beta_{1} x_{t 1}+\beta_{2} x_{t 2}+\ldots+\beta_{k} x_{t k}+\beta_{k+1} x_{t(k+1)}+\varepsilon_{t}$ Where:

- $\quad$ - y - means the dimensional column vector of observations made in n-elements sample on the dependent variable $\mathrm{Y}$;

- $\quad-\beta$ means $(\mathrm{k}+1)$ dimensional column vector of parameters called multiple regression factors;

- $\quad$ X means a $(\mathrm{n} *(\mathrm{k}+1))$ dimensional matrix of observations made in an n-elements sample on $k+1$ independent variables;

- $\quad-\varepsilon$ - random expression.

The set of independent variables should be reduced to relevant variables. The model should include variables that are strongly correlated with the dependent variable and at the same time the least correlated with each other. For this purpose, sub correlations are estimated below, which indicate the relationship between a given variable $\mathrm{Xji}$ and the dependent variable $\mathrm{Y}$, taking into account its correlation with all the remaining variables.

Using Pearson's linear correlation coefficient, partial correlation between all combinations of pairs of Y-set variables and $\mathrm{Xij}$ sets was investigated. For this purpose, the following formula for the partial correlation coefficient has been used: [36]

$$
\rho_{Y X_{i} \mid X_{1} X_{2} \ldots X_{i-1} X_{i+1} \cdots X_{k}}=\frac{-C_{Y X_{i}}^{d}}{\sqrt{C_{Y Y}^{d} C_{X_{i} X_{i}}^{d}}}
$$

Where: where $\mathrm{Cd} x \mathrm{xi}, \mathrm{xj}$ is an algebraic complement to the Pxi,xj element.

As a result of complex calculations, it was observed that not all dependent variables are significantly correlated with the independent variable. Table 3 presents the results of significant variables, for which the $p$-value $<0.05$.

Table 3. Partial correlation coefficients for significant variable pairs in the regression model

\begin{tabular}{|l|l|l|l|l|l|l|}
\hline $\begin{array}{l}\text { Dependent } \\
\text { variables }\end{array}$ & \multicolumn{2}{|l|}{ Challenges } & Barriers & \multicolumn{2}{l|}{ Trends } \\
\hline $\begin{array}{l}\text { Independent } \\
\text { variable }\end{array}$ & $\begin{array}{l}\text { Timeliness } \\
\text { of the } \\
\text { project } \\
\mathrm{X}_{\mathrm{W} 1}\end{array}$ & $\begin{array}{l}\text { Meeting } \\
\text { customer } \\
\text { requireme } \\
\text { nts } \mathrm{X}_{\mathrm{W} 2}\end{array}$ & $\begin{array}{l}\text { Proper } \\
\text { planning } \\
\text { of } \\
\text { activities } \\
\mathrm{X}_{\mathrm{W} 6}\end{array}$ & $\begin{array}{l}\text { Lack } \\
\text { resources for } \\
\text { effective } \\
\text { project } \\
\text { management } \\
\mathrm{X}_{\mathrm{B} 6}\end{array}$ & $\begin{array}{l}\text { Implementatio } \\
\mathrm{n} \text { of modern } \\
\text { project } \\
\text { management } \\
\text { methods } \mathrm{X}_{\mathrm{T} 1}\end{array}$ & $\begin{array}{l}\text { Increased } \\
\text { importance of } \\
\text { mega-projects } \\
\mathrm{X}_{\mathrm{T} 6}\end{array}$ \\
\hline $\begin{array}{l}\text { Project } \\
\text { implementation } \\
\text { time (Y) }\end{array}$ & 0.452 & 0.321 & 0.432 & 0.432 & 0.542 & 0.340 \\
\hline
\end{tabular}

Source: own calculations

Identified relevant dependent variables within the regression model. In order to check whether the regression model is relevant, a further analysis of variance was carried out, the results of which are presented in Table 4.

Table 4. Results of variance for the model

\begin{tabular}{|c|l|c|c|c|c|c|}
\hline \multicolumn{2}{|c|}{ Model } & Sum of squares & df & Mean square & F & Significance \\
\hline \multirow{3}{*}{1} & Regression & 2.558 & 1 & 2.558 & 9.082 & 0.005 \\
\cline { 2 - 7 } & Rest & 9.012 & 32 & 0.282 & & \\
\cline { 2 - 7 } & Total & 11.570 & 33 & & & \\
\hline \multirow{2}{*}{2} & Regression & 4.272 & 2 & 2.136 & 9.074 & 0.011 \\
\cline { 2 - 7 } & Rest & 7.234 & 31 & 0.235 & & \\
\cline { 2 - 7 } & Total & 11.506 & 33 & & & 0.040 \\
\hline \multirow{2}{*}{3} & Regression & 4.258 & 3 & 2.012 & 8.014 & \\
\cline { 2 - 7 } & Rest & 7.312 & 30 & 0.201 & & \\
\hline
\end{tabular}




\begin{tabular}{|l|l|c|c|c|c|c|}
\hline & Total & 11.570 & 33 & & & \\
\hline \multirow{4}{*}{4} & Regression & 5.341 & 4 & 2.531 & 8.001 & 0.021 \\
\cline { 2 - 7 } & Rest & 6.133 & 29 & 0.421 & & \\
\cline { 2 - 7 } & Total & 11.474 & 33 & & & \\
\hline \multirow{3}{*}{5} & Regression & 5.244 & 5 & 2.451 & 8.010 & 0.001 \\
\cline { 2 - 7 } & Rest & 6.315 & 28 & 0.342 & & \\
\cline { 2 - 7 } & Total & 11.559 & 33 & & & 0.023 \\
\hline \multirow{2}{*}{6} & Regression & 3.425 & 6 & 1.753 & 8.192 & \\
\cline { 2 - 7 } & Rest & 8.155 & 27 & 0.321 & & \\
\cline { 2 - 7 } & Total & 11.580 & 33 & & & \\
\hline
\end{tabular}

Source: own calculations

Based on the table above, it can be observed that a model with six predictors explains more variances than a model with one predictor. The value of the $\mathrm{F}$ statistics for this model for $\mathrm{p}<0.01$ means that the model explains to a large extent the variability of the implementation time for the project approach in enterprises.

As a result of step-by-step input of data, the following regression results were finally obtained, as shown in Table 5 .

Table 5. Modelling results after introduction of dependent variables

\begin{tabular}{|c|c|c|c|c|c|c|}
\hline & \multicolumn{6}{|c|}{$\begin{array}{l}\text { Summary of the dependent variable. } \mathrm{R}=0.7753 ; \mathrm{R}^{\wedge} 2=0.5234 \text { Corr. } \mathrm{R} 2=0.4942 \\
\mathrm{~F}(1,28)=7.031 \mathrm{p}<0,0021 \text { Std. error of estimation } 2.050\end{array}$} \\
\hline & $b^{*}$ & $\begin{array}{l}\text { Std. error } \\
\text { from b* }\end{array}$ & $\mathrm{b}$ & $\begin{array}{l}\text { Std. error } \\
\text { from b }\end{array}$ & $\mathrm{t}(65)$ & $\mathrm{P}$ \\
\hline Intercept & & & 1213.7 & 2676.65 & 4.2324 & 0.0001 \\
\hline $\begin{array}{l}\text { Timeliness of the } \\
\text { project } X_{\mathrm{W} 1}\end{array}$ & 1.0547 & 0.1125 & 1.436 .2 & 8001.2 & 9.3512 & 0.0012 \\
\hline $\begin{array}{l}\text { Meeting customer } \\
\text { requirements } \mathrm{X}_{\mathrm{W} 2}\end{array}$ & -0.3425 & 0.1021 & -0.8123 & 0.381 & -3.263 & 0.0032 \\
\hline $\begin{array}{l}\text { Proper planning of } \\
\text { activities } X_{\mathrm{W} 6}\end{array}$ & 0.7831 & 0.1512 & 0.7251 & 32.833 & 0.3210 & 0.0490 \\
\hline $\begin{array}{l}\text { Lack of resources for } \\
\text { effective project } \\
\text { management } \mathrm{X}_{\mathrm{B} 6}\end{array}$ & -0.4362 & 0.1621 & -0.3521 & 0.1216 & 0.3513 & 0.0382 \\
\hline $\begin{array}{l}\text { Implementation of } \\
\text { modern project } \\
\text { management } \\
\text { methods } \mathrm{X}_{\mathrm{T} 1}\end{array}$ & 0.5642 & 0.3571 & 0.5123 & 0.3264 & 0.1412 & 0.0001 \\
\hline $\begin{array}{l}\text { Increased } \\
\text { importance of mega- } \\
\text { projects } \mathrm{X}_{\mathrm{T} 6}\end{array}$ & -0.2314 & 0.3741 & -0.4627 & 5.6832 & 0.6414 & 0.0423 \\
\hline
\end{tabular}

Source: own calculations

The model presented above is the final model and explains nearly $52 \%\left(\mathrm{R}^{\wedge} 2\right)$ of the dependent variable variance. The explanation of $R^{\wedge} 2$ is satisfactory for the final model. The standard error of estimation was approx. 2.05. The final model can be formulated as: 
$\mathrm{Y}=1213.7+1.436 .2 * \mathrm{X}_{\mathrm{W} 1}-0.8123 * \mathrm{X}_{\mathrm{W} 2}+$ $0.7251 * \mathrm{X}_{\mathrm{W} 6}-0.3521 * \mathrm{X}_{\mathrm{B} 6}+0.5123 * \mathrm{X}_{\mathrm{T} 1}-$ $0.4627 * \mathrm{X}_{\mathrm{T} 6}$

On this basis, a substantive evaluation of the modelling results can be carried out.

The regression model, taking into account six predictors, significantly better predicts the time of project implementation in the company than using only single variables. All predictors simultaneously have a different influence on the project implementation time. When interpreting the obtained values of the coefficients, it should be stated that the higher the rating of the timeliness of the project, proper planning of activities and implementation of modern project management methods, the shorter the project implementation time. Project implementation time will also be shorter if the assessment regarding the need to meet customer requirements, lack of resources to manage projects effectively and the increased importance of mega-projects and the associated complexity of the project are low. These factors affect both the implementation of a single project and a group of projects in the surveyed entities. Better organized project planning and management activities with the use of modern tools and lower levels of lack of resources as well as lower levels of complexity of the project result in shorter implementation of the project approach in the activities of such entities.

\section{Conclusion}

The issues of project management in the context of challenges and conditions of the organisation's activities confirm the importance of the decisionmaking relationships noted above. Their basis is determined by the methods of project preparation and implementation, which present selected methodological bases of general context. Among them a detailed method based on multiple regression models was distinguished. The analyses enabled a calculation of the average ratings of the challenges, barriers and trends in project management. The following are of predominant importance in the challenges: timeliness of the project, meeting customer requirements, motivating team members and achieving the objectives set as well as effective project risk management. Planning, budgeting and team communication were considered less important. The systematisation of barriers indicates that the lack of management assistance, disruption of the organisational culture and lack of resources are of paramount importance. Further on, among the barriers were decisions of failure to see the benefits of project management in the company and increasing its efficiency through projects. To guide project management it is necessary to assess trends in this area of management processes. The dominant feature is the implementation of modern project management methods along with the development of interorganisational projects, as well as the adaptation of innovative technologies to support the management personnel. The remaining of the distinguished trends are non-financial increase in motivation, preferring sustainable development problems. In the context of the results, the hypothesis that the project implementation time is determined by challenges, barriers and trends in project management was confirmed. The hypothesis was on the basis of results received from the regression model. The main result is that the quicker application of new project management methods, the shorter the project implementation time. The rank of mega-projects and international projects certificates were lower in the ranking.

It is important to emphasise the importance of determinants in project management. By changing the activities of the organization, projects enable their development and functioning.

The study has certain implications for further research and practice of project management. The developed model expands existing theories in project management and shows challenges, barriers and trends.

In conclusion, project management can contribute to the planning and controlling for change processes and complexity by inserting modern project methods in managerial activities.

\section{References:}

[1] Taraba P., Project management methods in conditions of business companies in the Czech Republic, International Journal of Circuits, Systems and Signal Processing, pp. 46-52, Volume 13, 2019.

[2] Bakulina G., Fedoskin V., Pikushina M., Kukhar V., Kot E., Factor Analysis Models in Enterprise Costs Management, International Journal of Circuits, Systems and Signal Processing, pp. 232-240, Volume 14, 2020.

[3] Knop L., Brzóska J., Regionalne obserwatorium specjalistyczne - narządzie wdrażania regionalnej strategii innowacji $\mathrm{w}$ województwie śląskim (Regional specialist observatory - an instrument for the implementation of the regional innovation strategy in the Silesian province), [in:] Zarzadzanie organizacja (Organisational Management) ed. Grabowska M., Ślusarczyk 
B., Wydawnictwo Wydziału Zarządzania Politechniki Częstochowskiej, Częstochowa, 2017, pp. 87-100.

[4] Skowron-Grabowska B., Jasińska K., Zarzadzanie wiedza $w$ projektach organizacji oświatowych $w$ województwie ślaskim (Knowledge Management in the Projects of Educational Organisations in the Silesian Province), Wydawnictwo Politechniki Częstochowskiej, Częstochowa, 2019.

[5] Brdulak H., Metodyka zarządzania projektem w oparciu o praktykę firm logistycznych (Project management methodology based on the practice of logistics companies), [in:] Zarzadzanie projektami logistycznymi (Management of Logistic Projects) ed. Witkowski J., Skowrońska A., Research Papers of the Wroctaw University of Economics and Business no. 11, Wrocław, 2008, pp. 15-27

[6] Sherhar A.J., Dvir D., Nowe spojrzenie na zarzadzanie projektami (Reinventing Project Management), Wyd. Promise, 2008.

[7] Trocki M., Kompleksowa ocena projektów (Comprehensive Project Assessment), Studia $i$ Prace Kolegium Zarzadzania $i$ Finansów, Zeszyt Naukowy (Studies and Articles of the College of Management and Finance, Scientific Papers) no. 113, SGH, Warsaw, 2012, p. 17

[8] Wiśniewska J., Podstawy zarządzania projektami (Elementary project management), [in:] Zarzadzanie projektami $w$ organizacji (Project Management in an Organisation), ed. Janasz K., Wiśniewska J., Difin, 2014, p. 47, 49

[9] Illes C.B., Szuda C., Dunay A., Quality and Management - Tools for Continuous and Systematic Improvement of Processes, [in:] Management and Organization. Concepts, Tools and Applications, Pearson, 2017, pp. 99108.

[10] Hyotylainen T., Steps to Improved Firm Performance with Business Process Management. Adding Business Value with Business Process Management and its systems, Springer Gabler, 2015.

[11] Głodziński E., Project Governance - Istota, Dotychczasowe kierunki badawcze i perspektywy rozwoju (Project Governance Nature, Current Research Directions and Development Perspectives), Przeglad Organizacji (Organisational Review), no. 3, 2019, pp. 32-42.
[12] Walczak - Duraj D., Duraj J., Zintegrowany świat działalności komercyjno-społecznej przedsiębiorstw społecznych (Integrated world of the commercial and social activity of social enterprises), [in:] Zarzadzanie organizacją. Koncepcje. Wyzwania. Perspektywy. (Organisation Management. Concepts. Challenges. Perspectives), ed. Grabowska M., Ślusarczyk B., Wydawnictwo Wydziału Zarządzania Politechniki Częstochowskiej, Częstochowa, 2017, pp. 30-39.

[13] Rabl W., Project management, [in:] Business Project Management and Marketing. Mastering Business Markets, eds. Kleinaltenkamp Plinke W., Geiger I., Springer - Verlag Berlin Heidelberg, 2016.

[14] Skowron-Grabowska B., Seroka-Stolka O., Wójcik-Mazur A., Surowiec A., Pietrasieńśki P., Kultura organizacyjno-innowacyjna a działalność marketingowa przedsiębiorstw (Organisational and innovative culture and marketing activities of enterprises), [in:] Zarzadzanie organizacja. Koncepcje. Wyzwania. Perspektywy. (Organisation Management. Concepts. Challenges. Perspectives), ed. Grabowska M., Ślusarczyk B., Wyd. Politechniki Częstochowskiej, Częstochowa, 2017, pp. 101-109.

[15] Emary El, J.M.M., Brzozowska A., Bubel D., Management of Organizational Culture as a Stabilizer of Change. Organizational Culture Management Dilemmas, CRC Press Taylor Francis Group, 2020.

[16] Kozina A., Rozmus S., Kompetencje negocjacyjne kierownika projektu (Negotiating competences of the project manager) [w] Zarzadzanie restrukturyzacja, Rozwój efektywności w obliczu zmian (Restructuring management, Development of effectiveness in the face of change), UE Kraków, Ed. Jaki A., Kowalik M, Rojek T., 2018, pp. 87-105

[17] Grondys K., Sukiennik K., Szczepanik T., Planowanie przedsięwzięć $\mathrm{W}$ działalności przedsiębiorstw produkcyjnych (Project planning in the activities of production companies) [in:] Zarzadzanie organizacja. Koncepcje. Wyzwania. Perspektywy. (Organisation Management. Concepts. Challenges. Perspectives), ed. Grabowska M., Ślusarczyk B., Wydawnictwo Wydziału Zarządzania Politechniki Częstochowskiej, Częstochowa, 2017, pp. 58-66.

[18] Gunter B., Project Cooperation, [in:] Business Project Management and Marketing. 
Mastering Business Markets, eds., Kleinaltenkamp M., Plinke W., Geiger I., Springer Verlag Berlin Heidelberg, 2016, pp. 355-393

[19] Wiśniewska J., Świadek A., Sukces i dojrzałość organizacji w zarzadzaniu projektami (Organisation success and maturity in project management) [in:] Zarzadzanie projektami $w$ organizacji (Project Management in an Organisation), ed. Janasz K., Wiśniewska J., Difin, 2014, pp. 68-92.

[20] Crestani I., Change Communication: Emerging Perspectives for Organizations and Practitioners, [in:] The Manangement Game of Communication, eds. Bronn P.S., Rementi S., Zerfas A., Emerald Group Publishing Limited, 2016, pp. 225-244.

[21] Marciszewska A., Jokiel G., Granice zarządzania projektami - ujęcie systemowe (Project management limits - systemic approach), Przeglad Organizacji (Organisational Review) no. 3, 2019, pp. 9-14.

[22] Piwowar-Sulej K., Granice przedsiębiorstwa zorientowanego na projekty - optyka pracobiorców (Limits of the project-oriented enterprise - employee perspective), [w:] Granice strukturalnej złożoności organizacji (Limits of Structural Complexity of the Organisation), ed. Sopińska A., Grzegorczyk S., Oficyna Wydawnicza SGH, Warsaw, 2014, pp. 197-206.

[23] Goździewska-Nowicka A., Zarządzanie projektami w małych i średnich przedsiębiorstwach (Project Management in Small and Medium-Sized Enterprises), Marketing $i$ Rynek (Marketing and the Market), no. 7, 2016, pp. 225-237.

[24] Karbownik A., Wybrane problemy w zarządzaniu publiczną szkołą wyższą (Selected problems in public university management), [in:] Jakubiec M., Barcik A. (ed.), Wielowymiarowość zarzadzania XXI wieku (Multiple Aspects of Management in the 21st Century), Wydawnictwo Naukowe Akademii Techniczno-Humanistycznej, Bielsko-Biała, 2018, p.115-123.

[25] Janasz K. Dylematy ryzyka w zarządzaniu projektami (Risk dilemmas in project management), [in:] Zarzadzanie projektami $w$ organizacji (Project Management in an Organisation), ed. Janasz K., Wiśniewska J., Difin, Warsaw, 2014, pp. 173-194.

[26] Kisielnicki J., Blockchain jako technologia przepływu informacji i wiedzy w zarządzaniu projektami (Blockchain as a Technology for the Flow of Information and Knowledge in Project Management), Przeglad Organizacji (Organisational Review), 2018, no. 8, pp. 3-9.

[27] Schatsky D.,Muraskin C. Beyond Bitcoin, Blockchain is Coming to Disrupt Your Industry, Deloitte University Press, New York, 2015.

[28] Plinke W. and ClaBen M., Pricing and Revenue Planning in the Project Business, [In:] Business Project Management and Marketing. Mastering Business Markets, (eds.) Kleinaltenkamp M., Plinke W., Geiger., Springer Verlag, Berlin Heidelberg, 2016, pp. 83-126.

[29] Bukłaha E., Juchniewicz M., Kluczowe wyzwania i bariery oraz trendy w zarządzaniu projektami $\mathrm{z}$ punktu widzenia projektów realizowanych w Polsce (Key Challenges, Barriers and Trends in Project Management from the Perspective of Projects Implemented in Poland), Przeglad Organizacji (Organisational Review) no. 3 2019, pp.14-20.

[30] Zawada M., Tomski P., Kucęba R., Smart Grid and Smart Metering in Terms of Increasing Efficiency of Power Management in the EU, Przeglad Organizacji (Organisational Review) no. 5, 2015, pp. 44-51.

[31] Kopczyński T., Ewolucja zarządzania projektami w dynamicznych uwarunkowaniach otoczenia (Evolution of project management in a dynamic environment), [w:] Granice strukturalnej ztożoności organizacji (Limits of Structural Complexity of the Organisation), Oficyna Wydawnicza SGH, Warsaw, 2014, pp. 219241.

[32] Barcik A., Kapitat intelektualny $i$ compliance $w$ procesach konstytuowania doskonatości systemów spolecznej odpowiedzialności organizacji (Intellectual Capital and Compliance in the Processes of Constitution of Excellence in Organisational Social Responsibility Systems), PWE, Warsaw, 2019.

[33] Gemuenden H., Schoper Y., Future Trends in Project Management, Survey Report 2015;

[34] Bredillet C.N., The Future of Project Management: Mapping the Dynamics of Project Management Field in Action, [in:] D.I. Cleland, R. Gareis (eds.), Global Project Management Handbook, 2nd Edition, McGraw-Hill, New York, 2006. pp. 3-1-324.

[35] Kloppenborg T., Opfer W., The Current State of Project Management Research: Trends, Interpretation and Predictions, Project 
Management Journal, Vol. 33(2), 2002, pp. 5-18.

[36] Syska J., Współczesne metody analizy regresji wspomagane komputerowo (Contemporary Methods of Computer-Aided Regression Analysis), Silesian University, Katowice 2014.
Creative Commons Attribution License 4.0 (Attribution 4.0

International, CC BY 4.0)

This article is published under the terms of the Creative Commons Attribution License 4.0 https://creativecommons.org/licenses/by/4.0/deed.e n_US 